\title{
Internationalisation as a Democratic Tool: Revisiting Mexico's Double Transition
}

Pablo Calderon Martinez - Department of European and International Studies, King's College

\section{London.}

Abstract: Mexico's double transition - democratisation and internationalisation - offers a good case study to analyse the interaction between internationalisation processes and domestic developments during transitions to democracy. This paper explains how the specific way in which Mexico linked with North America worked as a causal mechanism during the country's democratisation. In the end, an inadequate project of internationalisation - spearheaded by the North American Free Trade Agreement (NAFTA) - failed to fulfil its democratising potential.

Keywords: NAFTA, Mexico, Democratisation, Internationalisation, Linkage-Leverage Democratisation, Mexico-USA relations.

\section{Introduction}

This article seeks to explore how Mexico's internationalisation project interacted with the democratisation of the country. Although I do not pretend to develop a theory of the role which internationalisation plays in democratisation processes, this article advances the idea that the way in which a country in transition to democracy relates to the international can have a major impact on the outcome of the said transition. Only a handful of countries have been as susceptible as Mexico was to international pressure during their democratisation process; yet, probably no other country has been as unsuccessful at institutionalising democracy, despite such high levels of economic integration and overall linkage with highly democratic nations. This article, then, presents a clear picture of how Mexico's specific project of internationalisation, through NAFTA, induced some democratic changes but fell short of capitalising on its potential. 


\section{Democratisation, Multicausality and Internationalisation}

Although modernisation theory, broadly understood, has dominated the debate surrounding democratisation, it is now generally accepted that 'many possible causal factors potentially operate in any given context' (Franzese, 2007: 36); this helps to explain why, although most people around the world would prefer to live under some sort of democratic regime (Fukuyama, 2011: 11; Plattner, 2009: 3), this does not always happen. Multicausal approaches towards democratisation, although not new (Diamond et al, 1995; Linz and Stepan, 1996), are now generally preferred over other monocausal explanations; indeed modernisation, culturalist/functionalist, institutional and elitist explanations of democracy no longer convince. This emphasis on multicausality has led to 'mechanism-based explanations' in the social sciences, which emphasise that 'proper explanations should detail the cogs and wheels of the causal process through which the outcome to be explained was brought about' (Hedström and Ylikoski, 2010), rather than merely focusing on causal correlations and statistical explanations.

However, despite these methodological developments, international considerations on democratisation processes remained, until fairly recently, underestimated. This is hardly surprising, since most transitions to democracy since World War II have been processes dominated by domestic cleavages, in which international factors have only been 'conducive' to change (Huntington, 1991: 58-108). Hence, despite some scholars having explored the role which the international context plays in transitions to democracy (Garrett and Lang, 1995; Pridham, 1995; Whitehead, 1996), the international context has mostly been overlooked or underestimated (Boix and Stokes, 2003; Higley and Burton, 1988; Huntington, 1991; Inglehart, 2000; Inglehart and Welzel, 2005; Linz and Stepan, 1996; Przeworski and Limongi, 1997), although, admittedly, the recent and controversial policies of democracy-promotion, adopted by the United States, the EU and other democratic actors, have 
provoked an increased interest in the subject (Brown and Kaufman, 2011:241). This policy shift and growing academic interest, however, is yet to lead to a reformulation of democratisation theory that accounts for the increasing role of international factors.

What is more, democracy-promotion is not, in many cases, directly related to how a specific country decides to internationalise. In fact, it has been argued that efforts (mainly from the United States) to assist democracy and shape economic policy 'often work at cross purposes'; economic internationalisation often undermines democracy-promotion efforts (Bermeo, 2009: 259). The case of Mexico, as will be discussed later, elucidates this point; economic internationalisation through NAFTA was not necessarily positive for Mexico's democratisation. It is also true that the so-called third-wave democratisations are taking place in an increasingly interlinked world. In spite of how easily the concept is thrown around, there is a need to account for the fact that, although 'globalisation' is not synonymous with internationalisation, there is a correlation between the two processes. As countries become more intertwined, the significance of the dynamics of internationalisation in the processes of democratisation has to be reconsidered. Departing from a definition of the political system as a "patterned interaction of rôles affecting decisions backed up by the threat of physical compulsion' (Almond, 1956: 395) - in which the term 'rôles' refers to the way that groups (armies, bureaucracies, political parties, social groups, international context, etc.) or individuals interact to construct the system, and the term 'patterned interaction' refers to the way that the rôles influence each other - we could conclude that 'a significant change in any one rôle affects changes in the others, thereby changing the system as a whole' (ibid). For example, 'when the rôle of political communication is transformed by technology this transforms the electoral process, political parties, etc.' (ibid: 396-397). In a similar vein, the increase in the salience of the international context, by influencing the calculations and access to resources available to different actors, must be transforming the system.

It is also worth noting that, whilst the term globalisation describes the process of increasing 
integration of the globe, internationalisation refers to the specific way in which a country 'relates' to the international. In economic terms, internationalisation is understood as the 'successful constitution of transnational markets' facilitated by a wide range of 'economic and technological interdependencies' (Knill and Lehmkuhl, 2002: 41-42). The focus of this paper, however, is to analyse what is, inherently, a political construct. Therefore, what is important to understand is that this 'successful constitution of transnational markets coincides with the inability of governments to address social and political problems that are emerging from economic integration, both at the national and the international level' (ibid: 42). In other words, there is a clear disparity between economic and political internationalisation. This is down to the fact that designing, agreeing on and implementing political structures (or even coordinated policies) at a speed that can keep up with the dynamics of economic integration is almost impossible to achieve (as the recent EU crises can probably attest); but this does not mean that governments are not trying. Either as a response to increasing economic internationalisation or as conscious attempt to solve political issues, political internationalisation has been advancing at a steady pace for the last six decades. The political attempt to 'catch up' with economic internationalisation is exactly what this paper seeks to address. As such, internationalisation could be understood as the combination of three dynamics: the internationalisation of problems on political agendas (e.g. climate change, terrorism and drug trade), the internationalisation of societies for which politics are made (migration, cultural homogenisation and media) and the internationalisation of the making of political decisions (e.g. international organisations and international summits) (Goldmann, 2001: 9). A project of internationalisation refers to the way in which any one nation attempts to cope with these dynamics; in the case of Mexico, integration with North America was considered the best way to achieve this objective.

\section{Incomplete or Failed Democratisation? Mexico's Experience with Democracy}


Many adjectives have been used to describe Mexico's pre-democratic regime. During its first spell in power, the Partido Revolucionario Institucional's (PRI) control over the country lasted more than 70 years, fourteen presidencies and almost twice as many legislatures with absolute control of Congress, it took the PRI nearly 60 years to give up control of a state's governorship (Baja California in 1989), and it controlled (directly or indirectly) most social organisations for the better part of the twentieth century. Yet, the PRI has not only managed to live to fight another day (and win the fight, as it turns out) but it has done so by avoiding being labelled as outright authoritarian. Despite widespread criticism in intellectual circles - Mario Vargas Llosa once described the PRI regime as 'the perfect dictatorship' (El País, 1/9/1990) - the PRI has long regarded itself as 'unique' and in a never-ending process of democratisation (Aguayo Quezada, 2010). Just as the mythical character Keyser Soze claimed, in the film The Usual Suspects, that 'the greatest trick the devil ever pulled was convincing the world he didn't exist', so has the PRI 'convinced' an important section of Mexican society that the authoritarian regime was never quite as authoritarian (Davies and Brachet-Marquez, 1997). No more evidence of the PRI's ability to mask its own authoritarian past is needed than the party's victory in the July 2012 elections. Despite allegations of collusion with the media (The Guardian, 7/6/2012) and fixing of the pre-election polls - the main pollsters (Milenio GEA/ISA, Berumen, GEA, Consulta Mitofsky) consistently gave the PRI candidate a lead of anything between sixteen and 26 percentage points, whilst the actual margin of victory was less than seven per cent (Milenio, 3/7/2012) -, accusations of widespread vote 'buying' (Milenio 3/7/2012), political violence (Proceso, 1/7/2012; Milenio, 13/6/2012), the initial refusal by the left-wing Partido de la Revolución Democrática (PRD) to accept the results (Bloomberg, 4/7/2012), and the violent protests that accompanied Enrique Peña Nieto's Presidential inauguration, the PRI has now regained the presidency and remains the strongest party in both houses of Congress (239 out of 500 seats in the Chamber of Deputies and 52 out of 128 Senators). 
In transitological terms we could speak of a transition without consolidation, but this conceptual division is, in itself, incredibly problematic - especially when we are relating the process to the international environment (Pridham, 1995: 167) - and has been, to an extent, replaced by less strict dichotomies (Bejarano, 2011: 6-8). Regardless of how one chooses to understand this, the fact remains that, although, from 1997 onwards, elections in Mexico have been free, fair and overseen by a truly independent arbiter, the institutions established by the PRI were never really transformed (Dresser, 2005). Hence, Mexico now has a democratically elected president at the top of a diluted presidential system that was not designed to be a liberal democracy. The regime institutionalised by the PRI has survived almost intact, and it arguably remains capable of embracing 'most of the local and regional strongmen' whilst providing a strong enough structure to 'establish mechanisms for settling the disputes amongst them' (Seele and Peschards, 2010: 1). This is hardly the definition of a 'consolidated' democracy. At the same time, the gradual and electoral nature of the Mexican transition (Merino, 2003) did not lead to a foundational pact; a commitment by the different political elites to allow democratic governance (or in transitological terms a ruptura pactada (agreed break)) never took place. This fact, coupled with the lack of comprehensive reforms of the institutions (Mexico's current Constitution was written in 1917 and, although it has been amended over 200 times, it has not drastically transformed the political institutions), signals that the transition to democracy is, at best, yet to be completed.

\section{Democracy and Internationalisation: NAFTA from a Comparative Perspective}

The events surrounding the highly contested 1988 presidential election are probably better remembered as the 'beginning of the end' of Mexico's single-party rule. However, the early days of Carlos Salinas's presidency also signalled a radical change in the way that Mexico related to the international; from then on, Mexico's economic policy was transformed and autarky stopped being a 
viable option. Although the López Portillo (1976-1982) and De la Madrid (1982-1988) administrations had already started to open up to the world, they had done so for the 'wrong' reasons. López Portillo was emboldened by an oil bonanza that took him, in an attempt to rehabilitate the regime's image, to break with Mexico's 'non-intervention' tradition in international affairs and get involved in the Central American conflicts (Mazza, 2001: 14). Conversely, De la Madrid was very much forced to accept the usual neoliberal reforms pushed by the IMF and the US Treasury, once the inevitable end to the oil bonanza sparked a severe deficit crisis. By his own admission, De la Madrid - by appointing Gustavo Petriccioli (later to be appointed Mexican ambassador to Washington and one of Salinas' closest allies) as the head of the Mexican Treasury let Carlos Salinas take control of the country's economic policy as early as June 1986 (Castañeda, 1999: 198). This path (either chosen or imposed) led to the eventual ratification of NAFTA in the US Congress in November 1993 by a margin of 34 votes. This radical change in policy was accompanied by an exaggerated expectation and, according to a member of the Mexican delegation in charge of negotiating NAFTA, signified the end of Mexico's self-imposed 'exceptionalism' (interview with Luis de la Calle, 2010).

NAFTA's main distinctive feature is that it remains the only example outside Europe of a developing country attempting economic integration with highly developed democracies. Unlike the European experience, however, Mexico's integration with North America has not always been considered beneficial for Mexico's democratic development. Admittedly, the EU is a unique process of internationalisation that entails a whole process of Europeanisation; it is a unique phenomenon that formalises links of interdependence in institutional arrangements (Closa, 2001: 16-17). The influence of this highly institutionalised version of internationalisation in the democratic transitions of Southern Europe in the 1970s and of post-communist Europe in the 1990s, for example, is relatively easy to find. 
Despite European integration being a far more institutionalised process, the dynamics of the interaction between internationalisation and democratisation can be compared to the Mexican experience. This is particularly true if we compare Mexico's integration with North America with the Southern European cases of the late 1970s and early 1980s. When Spain started its transition to democracy after Franco's death in 1975, for example, the country also embarked in a project of internationalisation, spearheaded by integration with Western Europe. The European Economic Community (EEC) of the late 1970s and early 1980s, however, was a very different organisation to today's EU. EEC membership, for instance - and key to this discussion -, did not explicitly require a democratic regime (the 'Copenhagen Criteria' that require member states to have 'stability of institutions guaranteeing democracy, the rule of law, human rights and respect for and protection of minorities' (European Council, 1993) was not introduced until 1993); much like NAFTA, the EEC was primarily an economic treaty (although it was a customs union, rather than a mere free trade agreement); the political institutions we now know were considerably less developed (the European Parliament, for example, was not a directly elected assembly until 1979); and finally, cohesion and structural funds (and other tools to correct regional imbalances) were not institutionalised until the first stage of the 'Delors Plan' towards European Monetary Union in 1990. However, and despite these broad similarities, the role which these two organisations (and their members) played in the transitions to democracy of their democratising candidates differs drastically.

\section{The Elephant in the Room: Analysing Economic Growth}

Before analysing the shortcomings of NAFTA it is important to acknowledge its successes. It is fairly clear that NAFTA was successful in achieving its explicit goal: to increase trade between the three countries involved. At this point it is worth noting that, although NAFTA is technically a trilateral agreement between the United States, Mexico and Canada, the asymmetry between the 
three countries (Pastor, 2011: 18) has led to the treaty functioning basically as two bilateral treaties: one between the USA and Canada, and another between the USA and Mexico. Bearing this asymmetry in mind, there is a common view, even outside official circles, that NAFTA 'succeeded in fostering the growth of trade and investment, promoting economies of scale' but failed in meeting the 'hyperbolic expectations of many of its strongest advocates prior to its enactment' (Dominguez and Fernández de Castro, 2009: 105). The preamble to NAFTA's document is, understandably, characterised by a careful wording that avoids any hint of it being, in any way, anything other than an agreement to 'strengthen the special bonds of friendship and cooperation amongst the nations' by creating an 'expanded and secure market for the goods and services produced in their territories'. In this narrow sense NAFTA has been a success. According to the Office of the United States Trade Representative 'from 1993 to 2007, trade among the NAFTA nations more than tripled, from $\$ 297,000$ million to $\$ 930,000$ million' (USTR, 2008) - although these figures clearly ignore the 'dual bilateral' nature of NAFTA, it is clear that NAFTA has achieved its main goal of increasing trade between the partners.

However, as Robert Pastor points out, NAFTA's 'principal failure was its omissions', which has left the three countries without the capacity to 'anticipate, coordinate or plan for new shocks or take advantage of opportunities' (2003:1); NAFTA lacks the institutional tools to deal with political internationalisation. Nonetheless, if we were to follow the modernisation approach to democratisation - i.e. that socioeconomic development and industrialisation change a society in a way that makes democracy increasingly likely - measuring NAFTA's influence in Mexico's democratisation would be the same as measuring NAFTA's impact in Mexico's economic development. Admittedly, neither the link between socioeconomic development and democratisation is beyond doubt (Landman, 1999), nor is it easy to quantify just how much of an impact NAFTA had in Mexico's economic growth. However, consciously shying away from the first controversy (an analysis of the supposed causal relation between development and democracy is beyond the scope of 
this article), it could be said that most models of democratisation acknowledge that socioeconomic development cannot hurt democracy's prospects (Prezeworski and Limongi, 1997; Diamond et al, 1995). Supporters of NAFTA often refer to the impressive figures that have been achieved under NAFTA's structure in order to prove its positive impact on Mexico's economic performance. Official data present a link between NAFTA and economic growth, the increase in Foreign Direct Investment, a decrease of unemployment rates and the creation of better-paid jobs in Mexico (Secretaría de Economía, 2006). Nevertheless, although the collapse of the Mexican peso in 1995 did cause a severe economic crisis, Mexico's average economic growth rate of 2.7 per cent since 1994, which pales in comparison to the 3.3 per cent US average, is less than impressive.

The truth is that these 'achievements' are not even close to the expectations that preceded the signing of the treaty. Even more so, this 'success' pales in comparison with the economic transformations achieved by Southern European countries joining the EEC in the 1980s. By 1989, for example, European aid represented a staggering 1.5 per cent of Spanish GDP and, according to some estimates, EU-backed projects mobilised an average of about 3.4 per cent of Spanish GDP in the period between 1994 to 1999 (Pastor, 2003: 10). Spain's European-fuelled economic growth allowed Spain's per capita GDP to increase from 70 per cent of the EU's GDP per capita average in 1986 to 88 per cent in 2003 (the year before the enlargement to Eastern Europe lowered the EU's average). What is more, European social and regional policies (The European Social Charter, Title V of the Single European Act and Regional European Policy) made sure that economic growth did not promote further economic inequality. Regardless of how unfair the comparison may be, it is clear that, as far as economic gains go, NAFTA could have done far better.

\section{NAFTA and Non-economic Democratic Changes}

The case of Mexico, at best, elucidates how economic growth can have an impact on the end of 
authoritarianism but is not enough to predict democratic consolidation; Mexico's income was relatively high from the mid-1970s (when GDP per capita reached \$4500) but the highly institutionalised nature of the regime, combined with an international context that favoured stability over reform, helped the regime survive until the year 2000 (when GDP per capita was close to \$8500) (Magaloni, 2005). Therefore, besides it being hard to establish the degree of influence which NAFTA had in Mexico's economic development, it is more important to this discussion to analyse the impact which NAFTA (i.e. the preceding negotiations and the actual implementation of the agreement) had in Mexico's political system. One argument is that NAFTA allowed the PRI technocrats to contemplate political accountability without fearing economic collapse. Basically, under a centralised economy, the PRI had to be in control of the economy and politics; once the PRI rendered control of the economy to the forces of the market, it could allow for political reform without the fear of an economic meltdown. However, despite Salinas's claims to the contrary somehow bizarrely, Salinas defines his presidency as a 'Social Liberalism' that was later discredited by the negative propaganda of the 'neoliberals' and the 'neopopulists' after the Peso Crisis of 1995 (Salinas de Gortari, 2010: 158-160) - 'there is little evidence that [NAFTA's initiator] President Carlos Salinas de Gortari intended to fully democratise Mexico' (Cameron and Wise, 2004: 304). Regardless of his intentions, though, signing NAFTA did mean that the PRI rendered control of the economy for good.

NAFTA implied a whole set of economic reforms that led to a reduction of the size of the state; and, as the state got smaller, the ability of the PRI to use official resources to deal with social issues diminished (Levy and Bruhn, 2006; Middlebrook, 2004). Certainly the shrinking of the state started before NAFTA came into effect and was, to a great extent, the consequence of the devastating budget crisis that accompanied De la Madrid's presidency. However, a clear consequence of NAFTA is that the move towards neoliberalism became permanent; it was no longer a matter of need but a political and ideological choice. Thus, besides hurting the PRI's capacity to deal with every problem 
in a vertical, highly hierarchical manner, NAFTA introduced a whole new socioeconomic rhetoric in which populism had no place. Even when the regime introduced its Programa Nacional de Solidaridad (PRONASOL), it was unable to reap the usual rewards of direct patronage, as the local PRI caciques were bypassed (Levy and Bruhn, 1995: 182). NAFTA hurt the clientilistic network of the PRI, as it made the regime's intervention with market forces implausible. It would be naive to believe, however, that the Salinas administration did not anticipate this development.

In fact, it seems more likely that the Salinas administration was aware of this side effect but intended to use NAFTA to buy some time and slow down political reforms. The plan was simple: as NAFTA brought prosperity, the PRI would regain the confidence of the electorate; once the electorate was convinced that the PRI was the only party capable of running the economy, the old regime could use fear of economic collapse as an argument against political reform. Also, the PRI regime correctly calculated that signing NAFTA would gain them 'credibility' in the US. As Mexico slowly became the darling of the markets, the regime could 'indulge' in some of its typical antidemocratic practices without fear of international retaliation (Cameron and Wise, 2004). According to some estimates, some 300 activists from the leftist and anti-NAFTA PRD were murdered during the Salinas administration. The impressive recovery of the PRI in the federal elections of 1991 (obtaining 58.66 per cent of the votes for Senators and 58.47 per cent of the votes for simple majority Representatives) and the presidential elections of 1994 (gaining 48.7 per cent of the vote against the Partido Acción Nacional's (PAN) 25.9 per cent) suggests that things were going according to plan. The sudden and 'unexpected' peso devaluation of December 1994 changed everything. When the 1995 crisis hit, the hopes of the PRI to remain in control vanished almost as quickly as the value of the peso. Suddenly, besides applying pressure on the PRI's anti-democratic networks, NAFTA's failure to deliver the grossly exaggerated results that the PRI had promised led to a sudden loss of confidence in the regime. 'As consumer debt exploded in 1995 and purchasing power collapsed under a 30 per cent real adjustment of the peso, the Salinas team's opportunism in 
delaying adjustment and spurring growth through politically motivated election-year spending would haunt the ruling party for the remainder of the decade' (ibid: 316). As vast sectors of society lost confidence in the PRI's ability to handle the economy, political liberalisation became a real possibility.

The 1996 electoral reform was the first to be introduced at a time when the PRI could not have calculated that it was in a position to win the elections (Magolani, 2005: 135). As it turned out, as well as losing the race for Mexico City's first elected mayor, the PRI lost control of Congress for the first time in the 1997 elections. The PRI eventually lost the Presidency to the PAN's candidate Vicente Fox in 2000. National surveys indicate that the economy was a primary concern for the Mexican electorate coming into the 2000 elections; whilst in 199351.8 per cent had a favourable view of Salinas's management of the economy, by 2000 only 16 per cent of the interviewees thought that Ernesto Zedillo, Salinas's successor, had improved economic conditions (Durand Ponte, 2004: 275). Although there is little evidence to suggest that NAFTA directly contributed to the crisis, there is little doubt that the expectations created by the PRI were contradicted by the devastating effect of the 1995 crisis. At the same time, evidence suggests that the Mexicans' rejection of the PRI's management of the economy was not related to a rejection of NAFTA or the market reforms; even though less than 20 per cent of the population thought that the economic situation of the country was positive in the year 2000, over 52.3 per cent of Mexicans still regarded free trade and a market economy as the best system for Mexico (Latinobarometro, 2000). Whilst NAFTA and market reforms remained mostly on positive terms, the failure of the PRI to deliver on its own exaggerated promises partly prompted the electoral collapse of the party.

NAFTA also indirectly influenced other aspects of Mexico's transition. In authoritarian regimes power is, by definition, heavily centralised, which leads to local and regional governments becoming mere symbols of the regime without any actual power. As democratisation develops, power becomes decentralised and returns to the local and regional levels. In the case of Mexico, the 
centralisation of power was exacerbated by an exaggerated presidentialism that portrayed the head of state as an omnipotent yet accessible figure who was responsible for fixing even the smallest of problems. This carefully crafted idea of a sympathetic and powerful president, willing to deal with most issues, encouraged the average citizen to aim their petitions as high as possible, thus completely bypassing local governments and rendering them useless (Craig and Cornelius, 1980). NAFTA played a small role in changing this dynamic. From the mid-1980s and the early 1990s, Mexico's cities near the US border started to take a more active role in the environmental issues affecting this region. Since NAFTA's implementation, there has been a surge of programmes managed by border localities, thanks to the North American Development Bank (NADB) and Border Environment Cooperation Commission (BECC). The NADB and the BECC are the only development institutions emerging from NAFTA and their mission is to 'address environmental issues on the U.S-Mexico border' (URL http://www.nadbank.org/about/mission.asp [accessed 30/7/2012]); as such, they provide 'financial assistance to public and private entities involved in developing environmental infrastructure projects in the border region' (ibid). To date, the NABD has provided over $\$ 1,220$ millions in loans for projects on the border region and 95 of the 177 projects funded have been on the Mexican side of the border. This allowed border cities to access resources from the NADB and not depend entirely on the federal government to fund projects. However, the impact of NADB and BECC projects remains marginal and are, for the most part, rather unknown organisations on both sides of the border.

The Salinas administration also reportedly spent $\$ 16$ million on what must be one of the largest lobbying operations in history. The Mexican Diaspora was identified as useful asset in the PRI's PR campaign and the Home Town Associations (HTAs) were developed to try to get them involved (Ayón, 2010). The idea was to engage the Mexican community in the US whilst keeping them away from criticising the regime. The best way to achieve this was by getting them involved in localised projects. The Salinas administration conjured the two-for-one plan in which the federal government 
matched the donations from the Diaspora to their communities back in Mexico. This also allowed some municipal governments to gain access to resources outside the federal patronage. As remittances from Mexican immigrants in the US surpassed oil as the number-one source of dollars in the country, it became clear that the effort to get the Diaspora involved in local affairs had worked. This helped to raise the profile of some state and municipal governments, which have gone, since the transition to democracy, 'from a subordinate role to one of increasing political autonomy' (Guillén López, 2010: 189).

Nevertheless, although NAFTA opened opportunities for some local governments to gain access to resources outside the PRI's patronage, these were concentrated in a handful of northern localities and in the states with high number of emigrants (e.g. Guanajuato, Jalisco, Michoacán and Hidalgo). What is more, it is no longer clear if the rise in power at state level was actually a positive development for Mexico's democracy. Aguayo Quezada argues that as Mexico's governors now control so many resources outside the scope of federal control that they can now be real players in the federal elections and, more often than not, they tend to abuse this power (2010: 191-197). The notion that the PRI losing control of increasing parts of the country could only be positive for democracy is no longer an undisputed fact.

\section{NAFTA, the Elites and Leverage}

From the dynamics analysed so far, it could be said that NAFTA's influence in Mexico's democratic development is, at least, unclear. However, it is the impact that NAFTA had on the behaviour of Mexican elites that is most interesting about this process. Although not the first to note the influence that the international context has on the elites' behaviour during transitions to democracy, Levitsky and Way's (2005 and 2010) use of linkage and leverage offers a detailed explanation of how this happens. Leverage refers primarily to the 'power' which a given democracy (or group of 
democracies) has over an authoritarian regime or the amount of pressure that it is willing and able to put onto that regime to democratise. Whilst leverage can increase the cost of repression, electoral fraud or other government abuses, it is rarely sufficient to persuade regimes to fully democratise (2005: 22). However, when leverage is combined with linkage to Western democracies, it becomes a truly effective democratising instrument. Linkage not only raises the costs of undemocratic behaviour for the governing elites but also for everybody else. Businesses not only benefit financially from linkage but they also learn to play by democratic rules; civil-society groups not only benefit from the support of organisations with similar aims in other countries, but they also learn how to organise themselves better to defend democracy; a better educated mass of technocrats benefits from being part of a wide network of countries where they can perform their trade, expand their businesses or attend universities; wide sectors of society benefit from access to a wide range of information sources, entertainment, travel and technology. In short, 'when linkage is extensive, international influences may be decisive' (ibid: 33).

When a country embarks on a project of internationalisation, it recognises that linkage, as well as its susceptibility to leverage, will invariably increase. Mexico was no exception. What was exceptional was that Mexico's transition took place in an atmosphere characterised by an increasing linkage to the United States, yet also - by refusing to impose any political conditionality during NAFTA's negotiations and by refusing to criticise the PRI regime - by a complete lack of leverage. Cold War mentality could, to an extent, explain why the US policy towards Mexico prioritised stability over democracy, but it cannot explain why most American policy-makers regarded criticism against the PRI regime as counterproductive, well after it came to an end. For whatever reasons, though, this continuation of the policy towards Mexico may explain why, when NAFTA was being negotiated, there were no serious calls for any sort of political conditions. Based on their wider foreign policy, though, it seems likelier that both the Bush and Clinton administrations considered that free market reforms would invariably lead, as they did in post-communist Europe, to Mexico's 
democratisation. The fact that Carlos Salinas was regarded as a champion of a free-market economy more or less guaranteed Washington's support. His economics education in Harvard, it seemed, was evidence enough of his commitment to democratic reform. The fact that his $\mathrm{PhD}$ dissertation 'Public Investment, Political Participation, and System Support' - was very much a draft version of PRONASOL, which supposedly was introduced to alleviate extreme poverty but in reality worked more as a new version of the old PRI's patronage networks (Urzúa, 1997: 94), did not seem to deter the enthusiasm of American policy-makers. Immediately after the highly contentious elections of 1988 and even before he was officially announced as the winner, the American Embassy in Mexico had already publicly congratulated him on his victory; no major US newspaper even reported on the highly contentious nature of the elections (Aguayo Quezada, 2010: 116).

It is somehow puzzling that, despite the wave of democratisation in Latin America and the support that the US was showing to emerging democracies in the region, consecutive American administrations decided to remain quiet in the case of Mexico. There is certainly nothing new about the United States not supporting an emerging democracy (Mazza, 2001: 2). What is surprising is that, in the case of Mexico, US administrations not only did nothing to encourage democracy but actually went as far as supporting the PRI regime. The 1991-1992 Action Plan from USAID went as far as claiming that democracy-promotion activities in Mexico would be counter-productive (ibid: 66). The National Endowment for Democracy offered very little funding for democratic development in Mexico during the Reagan and Bush years or during the NAFTA negotiations; neither of its Republican (the International Republican Institute) or Democrat (National Democratic Institute for International Affairs) wings offered any support to opposition parties until the early 1990s, and even then it was rather limited. The absolute refusal to even raise the issue of political conditionality was a continuation of a policy of no-policy, and constituted a definitive missed opportunity to strengthen Mexico's democracy. Even the slightest signs of discontent in the US were enough to make the regime give some concessions, as the creation of the Comisión Nacional de los Derechos Humanos 
proves. The Mexican elites must have calculated that, although the US government had no intention of asking for any sort of political conditionality, both Bush and Clinton were still vulnerable to criticism by Congress or other interests groups that could use the PRI's democracy and human rights records as a pressure point to advance their own protectionist interests. Despite assurances by the Bush and Clinton administrations, both in public and in private, that they had no intention of pursuing an explicitly pro-democratic agenda with NAFTA, the regime's elite was so sensitive to events in the US that any sort of criticism from unofficial circles prompted a response.

A short comparison with the Spanish case again helps to illustrate how sensitive elites are to international pressure when transitions to democracy overlap with projects of internationalisation. It has even been argued that 'Europe as a political example was probably far more important for Spain [...] than the European Union as a set of material incentives' (Fishman, 2003: 40). NAFTA, in stark contrast, was imposed by a nondemocratic regime on Mexican society and, regardless of whether the majority of Mexicans agree with it or not, it cannot be regarded as an example of democratic policymaking. In any case, accession into the Common Market was for the elites at the helm of the transition an important incentive to democratise. The fact that the 'EEC was solidly democratic, and had "set up a stable pattern of rewards and disincentives" for would be members' (Linz \& Stepan, 1996: 113) meant that the elites were very sensitive to European opinion. It was widely believed that Spain's international ostracism and inability to join European institutions was down to the Franco regime; the majority of the population regarded the EEC as a 'symbol of democracy and development' and the elites, wanting to benefit from the EEC's reputation, understood that joining the Community was a 'decisive step for the consolidation of democracy' (ibid). At the same time, the EEC had made it very clear that political reform was a sin qua non for integration; the elites knew it and the population knew it. Whether or not this conditionality was a ploy (mainly French) to avoid dealing with the very serious challenges that Spanish integration would mean for the Common Agricultural Policy, is irrelevant. The fact is that Spanish elites from all sides perceived that 
democracy was a condition for European integration and, what is more, they all agreed that joining the Common Market was indispensable to secure Spain's economic development. Europe's insistence on democratic reforms - the 1962 Birkelbach Report already suggested that Spain would not be allowed to join until it became democratic - and the elites' calculations of the costs of not joining meant that the Spanish elites' sensitivity towards European opinion exponentially rose; thus the costs of repression or democratic regressions became higher with internationalisation. This sort of consensus at elite level was never reached in the case of Mexico.

On top of this, one has to consider the active role which individual European democracies took in supporting Spanish democracy. It is well documented that the Spanish Socialist Party (PSOE) developed strong links with the German SPD and the Swedish Socialists, who, in turn, offered financial and logistic support to the PSOE's electoral effort (Ortega Ortiz, 2008: 135). What is more, the PSOE's leader, Felipe González, took advantage of Willy Brandt's and Olof Palme's personal endorsement to convince the Spanish electorate that the PSOE was ready to head a democratic government (Blanco y Negro, 26/4/1975; Europa Press, 23/12/1975). One can only speculate on the outcome of the Mexican transition had US policy-makers shown a similar level of commitment to Mexico's democracy. The fact that no such pressure or support existed meant that the political elites in Mexico were comfortable engaging in less than democratic practices, as they did not see the economic agreement linked to their attitudes towards democracy (Gentleman and Zubek, 1992).

\section{Conclusion}

Whether intentional or not, it is clear is that Mexico's internationalisation through NAFTA had an impact on Mexico's transition. On the one hand, NAFTA may have contributed towards Mexico's economic growth, whilst its failure to deliver on a clear set of exaggerated promises caused a sudden drop of confidence in the PRI's ability to manage the economy. To a lesser extent, it could also be 
said that NAFTA played a part in reducing the regime's ability to control the economy and to channel state's resources towards clientilistic networks, as well as playing a minor role in the decentralisation of power. On the other hand, the almost paranoid refusal by the US government to consider any sort of democratic provisions as part of economic integration seems to have encouraged anti-democratic practices by the regime. Certainly, based on this one case study, it is not possible to affirm that the way a country internationalises will have a deciding impact on its democratisation process. However, it is possible to infer that - given that NAFTA played an important role in Mexico's democratisation without even trying - had there been a stronger will to apply any sort of leverage amongst American policy-makers, NAFTA's positive effects on Mexico's democratic transition would have been greater. Therefore, internationalisation projects should be considered when analysing transitions to democracy; in particular when there is a will to complement linkage with leverage and vice versa.

\section{References}

Aguayo Quezada, S. (2010) La Vuelta en U: Guía para Entender y Reactivar la Democracia Estancada. Taurus: Mexico City.

Almond G.A. (1956) ‘Comparative Political Systems’. The Journal of Politics, 18: 391-409.

Ayón, D. R. (2010) 'Taming the Diaspora: Migrants and the State, 1986-2006' in A. Selee and C. Peschard (eds), Mexico's Democratic Challenges: Politics Government and Society. Stanford University Press: Stanford, California. 
Bejarano, A. M. (2011) Precarious Democracies: Understanding Regime Stability and Change in Colombia and Venezuela. University of Notre Dame Press: South Bend, Indiana.

Bermeo, N. (2008) 'Conclusion: Is Democracy Exportable?’ in Z. Barany and R. G. Moser (eds), Is Democracy Exportable? Cambridge University Press: New York.

Blanco y Negro (1975) 'Tensiones internas en el socialismo'. Blanco y Negro, 26 April: 14.

Bloomberg (2012) 'Lopez Obrador alleges Mexico election fraud and seeks recount', Bloomberg, 4 July. URL http://www.bloomberg.com/news/2012-07-04/lopez-obrador-alleges-mexico-electionfraud-and-seeks-recount.html [accessed 4/7/2012]

Boix, C. and Stokes, S. C. (2003) ‘Endogenous Democratisation'. World Politics 54 (4): 517-549.

Brown, N. J. and Kauffman, C. M. (2011) ‘Introduction to Part III: Does Democracy Diffuse?’ in N. Brown (ed.), The Dynamics of Democratization: Dictatorship, Development and Diffusion, John Hopkins University Press: Baltimore.

Cameron, M. A. and Wise, C. (2004) 'The Political Impact of NAFTA on Mexico: Reflections on the Political Economy of Democratization', Canadian Journal of Political Science 37 (2): 301-323.

Castañeda, J.G. (1999) La Herencia: Arqueología de la Sucesión presidencial en México, Extra Alfaguara: Mexico City.

Closa, C. (ed.) (2001) La Europeización del Sistema Politico Español. Ediciones Istmo: Madird. 
Craig, A. L. and Cornelius, W. A. (1980) 'Political Culture in Mexico: Continuities and Revisionist Interpretations' in G. Almond and S. Verba (eds), The Civic Culture Revisited,. Sage Publications: Thousand Oaks, California.

Davies, D. and Brachet-Marquez V. (1997) 'Re-thinking Democracy: Mexico in Historical Perspective'. Comparative Studies in Society and History 39 (1): 86-119.

Diamond, L., Linz, J..J. and Lipset, S. M. (eds) (1995) Politics in Developing Countries: Comparing Experiences with Democracy. Lynne Rienner Publishers: Boulder, Colorado.

Domínguez, J. I. and Fernández de Castro, R. (2009) The United States and Mexico: Between Partnership and Conflict, $2^{\text {nd }}$ Edition. Routledge: London.

Dresser, D. (2005) 'Mexico: Del Predominio del PRI a una Democracia Dividida', in J. I. Domínguez and M. Shafter (eds), Construcción y Gobernabilidad Democrática en América Latina,. Fondo de Cultura Económica: Mexico City.

Durand Ponte, V. M. (2004) Ciudadanía y Cultura Política: México 1993-2001. Siglo XXI: Mexico City.

El País (1990) Vargas Llosa, 'México es la dictadura perfecta', El País, Madrid, 1 September URL http://elpais.com/diario/1990/09/01/cultura/652140001_850215.html [accessed 5/6/2011] 
Europa Press (1975) Felipe González, 'Hay que salir de la dialéctica política del todo o nada'. 23 December: 5 .

European Council. (1993) European Council in Copenhagen - 21-22 June 1993 - Conclusion of the Presidency, Press Release (22/6/1993), http://europa.eu/rapid/press-release DOC-933_en.htm?locale=en [accessed: 6/2/2013]

Fishman, R. M. (2004) 'Shaping, not Making Democracy: The European Union and the Postauthoritarian Political Transformation of Spain and Portugal' in S. Royo and P.C. Manuel (eds), Spain and Portugal in the European Union: The First 15 Years, , Routledge: London.

Franzese, R. J. (2007) 'Multicausality, Context-conditionality and Endogeniety' in C. Boix and S. C. Stokes (eds), The Oxford Handbook of Comparative Politics, Oxford University Press: New York:.

Fukuyama, F. (2011) The Origins of Political Order: From Prehuman Times to the French Revolution, Profile Books Ltd: London.

Garrett, G. and Lang, P. (1995) 'Internationalisation, Institutions and Political Change'. International Organisation 49 (4): 627-655.

Gentleman, J. and Zubek, V. (1992) 'International Integration and Democratic Development: The Cases of Poland and Mexico'. Journal of Interamerican Studies and World Affairs 34 (1): 59-109.

Goldmann, K. (2001) Transforming the European Nation-State: Dynamics of Internationalisation, Sage Publications: London. 
Guardian (2012) 'Computer files link TV dirty tricks to favourite for Mexico presidency'. Guardian, 7 June. URL

http://www.guardian.co.uk/world/2012/jun/07/mexico-presidency-tv-dirty-tricks?INTCMP=SRCH [accessed 8/6/2012]

Guillén López, T.. (2010) 'Federalism and the Reform of Political Power', in A. Selee and C. Peschard (eds), Mexico's Democratic Challenges: Politics Government and Society,. Stanford University Press: Stanford, California.

Hedström P and Ylikoski P. (2010) 'Causal Mechanisms in the Social Sciences'. The Annual Review of Sociology 36: 49-67.

Higley, J. and Burton, M. G. (1988) 'The Elite Variable in Democratic Transitions and Breakdowns'. American Sociological Review 4 (1): 17-32.

Huntington, S. (1991) The Third Wave: Democratization in the Late Twentieth Century, University of Oklahoma Press: Oklahoma.

Inglehart, R. (2000) 'Culture and Democracy’ in L. E. Harrison and S. Huntington (eds), Culture Matters: How Values Shape Human Progress., , Basic Books: New York.

Inglehart, R. and Welzel, C. (2005) Modernisation, Cultural Change and Democracy, Cambridge University Press: New York. 
Knill, C. and Lehmkahl, D. (2002) 'Private Actors and the State: Internationalisation and Changing Patterns of Governance'. Governance 15 (1): 41-63.

Landman, T. (1999) 'Economic Development and Democracy: The View from Latin America', Political Studies 47(4): 607-626.

Latinobarometro, (2000). [WWW resource]. Resultados de Análisis en Línea: México. URL http://www.latinobarometro.org/latino/LATAnalizeIndex.jsp [accessed 1/8/2012]

Levitsky, S. and Way, L. A. (2010) Competitive Authoritarianism: Hybrid Regimes After the Cold War, Cambridge University Press: New York.

Levitsky, S. and Way, L. A. (2005) 'International Linkage and Democratisation'. Journal of Democracy 16 (3): 20-34.

Levy, D. C. and Bruhn, K. (1995) 'Mexico: Sustained Civilian Rule without Democracy' in L. Diamond, J.J. Linz and S.M. Lipset (eds), Politics in Developing Countries: Comparing Experiences with Democracy. Lynne Rienner Publishers: Boulder, Colorado.

Levy, D. C. and Bruhn, K. (2006) Mexico: The Struggle for Democratic Development. University of California Press: Los Angeles and Berkley.

Linz, J. J. and Stepan, A. (1996) Problems of Democratic Transition and Consolidation: Southern Europe, South America and Post-communist Europe, John Hopkins University Press: Baltimore. 
Magaloni, B. (2005) ‘The Demise of Mexico’s One Party Dominant Regime: Elite Choices and the Masses in the Establishment of Democracy', in F. Hagopian and S. P. Mainwaring (eds.), The Third Wave of Democratisation in Latin America: Advances and Setbacks, Cambridge University Press: New York.

Mazza, J. (2001) Don't Disturb the Neighbours: The United States and Democracy in Mexico. Routledge: New York.

Merino, M. (2003) La Transición Votada: Crítica a la Interpretación del Cambio Político en México, Fondo de Cultura Económica: Mexico City.

Middlebrook, K. J. (2004) 'Mexico's Democratic Transitions: Dynamics and Prospects', in K.J. Middlebrook (ed.). Dilemmas of Political Change in Mexico, Institute of Latin American Studies: London.

Milenio (2012) 'Escolta de ex candidato del PRI asesinó a brigadista del PAN: PGJ'. Milenio, 13 June. URL http://www.milenio.com/cdb/doc/noticias2011/d8474bf6cfd630b8b7c87039a4f3fe09 [accessed 2/7/2012]

Milenio (2012) 'Falló la encuesta MILENIO-GEA/ISA', Milenio, 3 July. URL http://www.milenio.com/cdb/doc/impreso/9152111 [accessed 3/7/2012]

Milenio (2012) 'Investigará consejero del IFE presunta compra de votos con tarjetas de Soriana', 3 July. http://www.milenio.com/cdb/doc/noticias2011/46e09ef345b9f7db7eefe4c0d2386575 [accessed 3/7/2012]. 
Office of the United States Trade Representative (2008). NAFTA Factsheet: NAFTA Myth Vs. Facts. [WWW document] Office of the United States Trade Representative: Washington, D.C. URL http://www.ustr.gov/sites/default/files/uploads/factsheets/2008/asset_upload_file71_14540.pdf [accessed 25/6/2011].

Ortega Ortiz, R. Y. 2008. Mobilización y Democracia: España y México. El Colegio de México: Mexico City.

Pastor, Robert A. 2011. The North American Idea: A Vision of a Continental Future. New York: Oxford University Press.

Pastor, R. A. (2003) 'Closing the Development Gap and Forging a Partnership: The Challenge of NAFTA's Second Decade'. Unpublished draft for conference Mexico's Changing Place in the World, Oxford University, 21-22 February.

Plattner, M. F. (2009) 'Introduction', in Z. Barany and R. G. Moser (eds), Is Democracy Exportable? Cambridge University Press: New York.

Pridham, G. (1995) 'The International Context of Democratic Consolidation: Sothern Europe in Comparative Perspective' in R. Günther, N. Diamandorous and H.J. Puhle (eds), The Politics of Democratic Consolidation: Southern Europe in Comparative Perspective,. John Hopkins University Press: Baltimore. 
Proceso (2012) 'Abundaron denuncias y filtraciones en las redes sociales'. Proceso, 1 July. http://www.proceso.com.mx/?p=312837 [accessed 3/7/2012].

Przeworski, A. and Limongi, F. (1997) 'Modernization: Theories and Facts'. World Politics 49 (6): $155-183$.

Salinas de Gortari, C. (2010) Democracia Republicana. Ni Estado ni Mercado: Una Alternativa Ciudadana. Random House Mondadori: Mexico City.

Secretaría de Economía, (2006). Con el TLCAN, en 12 Años se Triplicó el Comercio entre México, Estados Unidos y Canadá. Press Release $22^{\text {nd }}$ October.

Selee A. and Peschard J. (eds.) (2010) Mexico's Democratic Challenges: Politics, Government, and Society. Stanford University Press: Chicago.

Urzúa, C.M. (1997) 'Five Decades of Relations Between the World Bank and Mexico' in The World Bank: Perspectives, D. Kapur, J.P. Lewis and R.C. Webb (eds). The Brookings Institution: Washington D.C.

Whitehead, Lawrence (ed.) (1996). The International Dimensions of Democratisation: Europe and the Americas, Oxford University Press: Oxford.

\section{Interviews}

De la Calle Pardo, L. (2010) Former Trade and NAFTA Minister at the Mexican Embassy in Washington, DC (1994-1998) (15/1/2010), Mexico City 